\section{6th Annual Meeting of the Society for Cutaneous Ultrastructure Research}

Florence, April 22-24, 1999

Scientific Secretariat

SCUR ' 99 - Dr. Nicola Pimpinelli

Institute of Dermatology, University of Florence

Via degli Alfani, 37, I-50121 Florence (Italy)

Tel. +39 55 2344422, Fax +39 552758 381/2758 757

E-Mail pimpi@cesit1.unifi.it

Organizing Secretariat

C.S.S.

Viale Mazzini, 70

I-50132 Florence (Italy)

Tel. +3955 2480202, Fax +3955 2480246

E-Mail css@mega.it

\section{The Niels Hjorth Prize}

The International Contact Dermatitis Research Group encourages research by endowing a Niels Hjorth Prize $(£ \propto 1,500)$. Original, unpublished papers are invited, and a committee will select the winner. The winning entry will be presented as a paper at the 12th International Symposium on Contact Dermatitis in San Francisco in October 1999.

The deadline for submission of papers for the Prize is June 30, 1999. Please send 6 copies to the Chairman of the International Contact Dermatitis Research Group:

Prof. J.-M. Lachapelle

Unit for Occupational Dermatology

Louvain University, UCL 3033

30, clos Chapelle-aux-Champs

B-1200 Brussels (Belgium)

Tel. +3227643335

Fax +3227643334
The Cleveland Clinic Foundation: Dermatopathology Self-Assessment Workshop

Cleveland, October 2, 1999

Renaissance Hotel

Course Director: Wilma F. Bergfeld, MD

Head, Section of Dermatopathology, Departments of Dermatology and Pathology

For information contact:

Wilma F. Bergfeld, MD

Department of Dermatology A61, Cleveland Clinic Foundation

9500 Euclid Avenue, Cleveland, OH 44195 (USA)

Tel. +1 (216) 444 5722, Fax +1 (216) 2315448

\section{KARGER}

Fax +4161306 1234

E-Mail karger@karger.ch

www.karger.com
(C) 1999 S. Karger AG, Basel

$1018-8665 / 99 / 1981-0110 \$ 17.50 / 0$

Accessible online at: http://BioMedNet.com/karger 